\title{
Posisi dan Fungsi Mamak dalam Perubahan Sosial di Lingkungan Keluarga Matrilinial Minangkabau
}

\author{
Firman Firman \\ Jurusan Bimbingan dan Konseling FIP Universitas Negeri Padang \\ Email : firman@konselor.org
}

\section{A. Pendahuluan}

Suku Minangkabau termasuk salah satu suku terbesar, selain suku Jawa, Sunda Madura dan Bali, dengan jumlah $3 \%$ dari keseluruhan penduduk Indonesia . Perasaan sesuku bagi masyarakat Minangkabau didasarkan atas persamaan dasar bahasa, asal usul pengelompokan suku serta penduduk yang homogen bergama Islam (Budhisantoso,1988 :12). Kehidupan mereka berlandasaskan: adat basandi syarak, syarak basandi kitabullah (adat bersendikan syarak, syarak bersendikan kitabullah). Masyarakat Minangkabau merasa tercela apabila disebut orang yang tidak beradat dan tidak beragama.

Salah satu ciri yang menonjol dari suku Minangkabau adalah kebiasaan merantau dan sistim kekerabatan matrilineal yang menelusuri ikatan kekeluargaan melalui garis keturunan ibu. Sistim kekerabatan matrilineal Minangkabau mempunyai ciri, yaitu : (1) keturunan dan pembentukan kumpulan diperhitungkan menurut garus keturunan ibu, (2) perkawinan bersifat metrilokal, (3) anggota kelompok kerabat merasa bersaudara kandung, senasib, sehina dan semalu, (4) kekuasaan hakiki pada ibu dan teknis pada mamak dalam kaum, (5) pola tempat tinggal bercorak dwilokal, (6) kesatuan keluarga terkecil adalah paruik yang bersifat geneologis, serta (7) pusaka tinggi dari mamak kepada kemenakan (Malinowsky dalam Rajab, 1969: 17; Kato, 1989:54-55; Mardanas, 1991:9-10).

Setiap orang dalam keluarga matrilineal di Minangkabau menjadi anggota dari suatu kelompok yang terdiri dari ibu, ibunya, sadura perempuannya, saudara laki-laki dan perempuan ibunya. Prinsip dasar dalam kekeluarga matrilineal bertumpu pada 
ikatan keluargaan melalui garis keturunan ibu dan kaum perempuanlah penerus keturunan.

Garis keturunan dalam suku Minangkabau mempunyai arti dalam pewarisan harta puska. Sehubungan dengan hal itu, harta warisan terutama barang tetap memurupakan warisan turun temurun, seperti: sawah dan ladang jatuh kepada anak perempuan. Pewarisan harta dalam budaya Minangkabau hanya dalam arti pemanfaatan hasil pengelolaan untuk penghidupan. Pemindahan hak ditentukan syarat-syarat tertentu menurut adat, sedangkan pewarisan gelas pusaka yang disebut dengan sako digariskan kepada kemenakan laki-laki melalui mamak sebagai gelar jabatan dalam keluarga.

Ayah dalam keluarga Minangkabau tidak termasuk anggota keluarga istri dan anak-anaknya, sama halnya dengan seorang anak dari saudara laki-laki termasuk keluarga lainnya dari ayahnya. Sehubungan dengan hal itu, dalam masyarakat Minangkabau tradisional keluarga batih menajadi kabur karena tidak merupakan kesatuan yang mutlak, walaupun keluarga batih itu memengang peran penting dalam pendidikan dan masa depat anak-anaknya yang tidak hanya berfungsi untuk mengembangan keturunan saja (Naim, 1984:31).

Meskipun kelompok kekeluargaan di Minangkabau menelusuri keturunan melalui garis keturunan ibu, namun kelompok ini membiarkan laki-laki mengawasi masalah-masalah kelompo keturunan dengan melakukan kontrol sebagai saudar lakilaki ibu yang disebut dengan mamak. Di dalam kehidupan keluarga rumah gadang atau keluarga saparuik, mamak serta anggota keluarga lainnya dikoordinir oleh mamak yang dituakan karena kecerdasasan, umur, serta pandai dari yang lainnya disebut dengan mamak tunggai. Sedangkan dalam kehidupan yang lebih luas seperti suku, mamak dipimpin oleh penghulu bergelar datuk.

Secara umum mamak atau sadara laki-laki ibu berperan dalam mengurus kepentingan anggota keluarga yang tinggak bersama di rumah gadang termasuk memenuhi kebutuhan ekonomi keluarga, membimbing anak saudar perempuan (kemenakan), melaksanakan upacara adat, menyelesaikan masalah serta kepada keluarga yang mewakili keluarga di luar rumah gadang.

Sebagai sumber kehidupan ekonomi keluarga rumah gadang atau keluarga saparuik diambil dari harta pusak dalam bentuk sawah dan ladang yang dikelola serta 
diurus oleh mamak bersama keluarga lainnya. Mamak dalam masyarakat Minangkabau berkewajiban untuk menambah harta pusaka tersebut demi kesejahteraan kemenakan dan saudara perempuannya.

Hubungan antara saudara laki-laki ibu (mamak) dengan anak saudara perempuan (kemenakan), maka tebentuklah kesatuan hubungan bamamak bakamanakan (bermamak berkemenakan). Hubungan tersebut bersifat diagonal, yaitu sebagai mamak dari anak saudara perempuan dan sebagai kemenakan dari sauara lakilaki ibunya yang merupakan kesatuan hubungan keterladanan dalam adat Minangkabau.

Kemenakan dipandang sebagai pelanjut tradisi keluarga atau kaum karena harta pusaka, gelar pusaka (pusako) digariskan kepadanya. Mamak merupakan pelindung dan membina kemenakan sehingga dikemudian hari kemenakan dapat mengantikannya sebagai penanggung jawab dan penerus kelangsungan hidup keluarga. Bimbingan mamak datuk atau kepala suku, mamak tungganai (pemimpin rumah gadang) serta mamak lainnya terhadap kemenakan sangat diharapkan sebagai pewaris anggota rumah gadang kemudian hari. Begitu juga sebaliknya mamak tanpa memeliki kemenakan ibarat tambek nan indak baransang, idjuak nan indak basaga. Maksudnya kemenakan diharapkan sebagai pelindung kaum kerabat, penyambung garis keturunan dan pewaris harta pusaka.

Adat Minangkabau memberikan kekuasaan kepada saudara laki-laki ibu yang disebut mamak untuk menegakkan jika perlu memaksakan norma-norma yang diharapkan dipatuhi oleh warga kaumnya, atau paling kurang oleh kemenakannya. Dalam bertindak mamak tunggani sebagai kapalo paruik (kepala keluarga satu nenek) dilakukan dengan memusyawarahkan persoalan-persoalan penting dengan seluruh anggota keluarga laki-laki atau wanita (Bachtian,1963:64).

Sehubungan dengan uraian tersebut, seorang mamak datuk (kepa suku) mamak tunganai (pemimpin rumah gadang) serta mamak lainnya disengani, diteladani, tempat bertanya serta tempat belajar oleh kemenakannya. Hubungan mamak didasarkan kepada musyawarah. Segala aktifitas bersama di lingkungan keluarga rumah gadang, mamak tunggai atau pimpinan rumah gadang serta mamak lainnya ikut berpartisipasi. 
Di sisi lain, mamak datuk, mamak tungganai (pimpinan rumah gadang) serta mamak lainnya yang sudah menikah berperan sebagai bapak dari anak-anaknya. Secara tradisional sumando (suami saudara perempuan) di lingkungan keluarga istrinya tidak ada tuntutan kecuali untuk kepentingan keturunan, karena anak dan istrinya sudah dipertanggung jawabkan oleh saudara laki-lakinya (mamak).

Berkenaan dengan hal itu, Sanderson (1991) mengemukan bahwa dalam keluarga yang menganut sistem matrilineal menimbulkan dua jenis keayahan yang mendasar, yaitu keayahan biologis dan keayahan sosiologis. Seoranglaki-laki yang telah menikah menjadi ayah biologis bagi putra-putranya sendiri. Hal ini sering menimbulkan ketegang bagi masyarakat matrilinial. Sebagai ayah sosiologis laki-laki mempunyai tanggung jawab utama untuk mengasuh anak laki-laki saudara perempuannya.

Dewasa ini perubahan sosial terjadi dalam masyarakat Minangkabau, yang telihat dari struktur kekeluargaan matrilinial itu sendiri. Keluarga samande (satu ibu) terdiri dari suami, istri serta anak-anak semakin menonjol dibandingkan keluarga saparuik (satu nenek) yang terdiri dari nenek, anak-anak serta cucunya yang hidup di rumah gadang, sasuku (kumpulan kerabat saparuik) serta sakampuang yang sebelumnya mewarnai kehidupan masyarakat Minangkabau.

Tanggung jawab suami untuk memenuhi kebutuhan anggota keluarga samande (satu ibu) semakin kelihatan dibandingkan dengan mamak (saudara laki-laki ibu). Bapak mempunyai pengaruh yang besar dalam menentukan rencana masa depan anakanaknya yang dulu diperankan oleh mamak (saudara laki-laki ibu). Masa silam seorang suami dalam masyarakat Minangkabau tidak diwajibkan memberi nafkah istri dan anak-anaknya karena sudah dipenuhi oleh saudar laki-laki istri (mamak) dengan mengelola harta pusaka dalam bentuk sawah dan ladang.

Secara tradisional menurut adat Minangakbau suami yang disebut orang sumando tidak termasuk anggota keluarga istri dan anak-anaknya, melainkan anggota kerabat ibunya. Di dalam keluarga istri suami tidak mempunyai kekuasaan atas anak atas istri tetapi mempunyai hak kunjung terutama di malam hari. Suami lebih banyak berada di lingkungan kerabat ibunya karena menurut adat laki-laki harus berusaha memakmurkan kaum dengan menambah harta posuka ibu yang diperuntukan untuk 
saudar perempuan. Laki-laki tidak memegang harta kecuali yang memangku jabatan sebagai kepala kaum (penghulu) untuk menopang biaya menjalankan tugasnya .

Perubahan dalam sturuktur keluarga matrilinial di Minangkabau menuntut mamak untuk berdaptasi agar kehidupan keluarga stabil. Proses adaptasi terhadap perubahan yang terjadi akan menyebabkan paling tidak meninggalkan kebiasaan lama dan menerima kebiasaan baru. Dengan arti kata mamak akan berdaptasi secara budaya terhadap sesuatu yang baru karena sebelumnya tidak pernah ada dalam sistim budaya Minangkabau.

Berdasarkan uraian terebut menarik ditelusuri lebih lanjut melalui tulisan ini bagaimana posisi dan perubahan fungsi mamak dalam masyarakat matrilinial di Minangkabu. Pengungkapan fenomena tersebut bermanfaat untuk memahami serta mengambil kebijakan yang sesuai kondisi sosial budaya masyarakat Minangkakabau yang sedang berubah.

\section{B. Perubahan Posisi Mamak dalam Keluarga di Minangkabau}

Selepas Abad 19 Pemerintah Hidia Belanda memperkenalkan ekonomi berorientasi eksport di Sumatra Barat, tidak lama kemudian pertanian sub sistim berubah menjadi pertanian berorientasi ekspor. Beriringan dengan hal itu, Pemerintah Belanda juga menanamkan kekuasaan politiknya di Minnagkabau (Kato,1989:159).

Awal kedatangan Belanda di Minangkabau, mereka berusaha mencapai keamanan situasi dengan megadakan persetujuan damai dengan pemuka masyarakat. Pesetujuan tersebut menyepakati bahwa Kompeni Belanda tidak akan mencapuri urusan nagari terutama menyangkut masalah adat.

Setelah ditandatangani perjanjian pelakat panjang, Belanda mulai meletakan sturuktur politiknya di Minangkabau, dengan mengangat penghulu sebagai wakil kompeni. Selanjutnya Belanda membentuk dewan rakyat yang dipimpin Kapalo Nagari (kepala negeri). Dewan rakyat akhirnya tumbuh menjadi Kerapatan Adat Nagari (KAN) yang beranggotakan penghulu atau orang terkemuka lainnya menurut kebiasaan adat nagari setempat. Kerapatan Adat Nagari bertugas mengangkat kepala nagari. Kepala nagari selanjutnya berhubungan dengan serangkaian struktur kolonial yang lebih tinggi, 
seperti asisten Demang, Demang Contraleur, Asisten Residen dan sebagainya (Hasbi, 1989:13).

Sistim pemerintah yang diciptakan Belanda tersebut, membuat kekuasaan penghulu sebagai pemimpin suku mulai memudar. Pengangkatan salah seorang penghulu sebagai kepala pemerintahan nagari meletakan kekuasaan penghulu lainnya lebih rendah. Penghulu dengan kemenakannya sering terjadi konflik karena berbenturan tugas yang digariskan pemerintah Kompeni dalam menarik pajak dengan kepentingan kemenakan, sehingga wibawa penghulu mulai hilang di mata kemenakannya.

Berakhirnya Pemerintahan Belanda diganti oleh Pemerintahan Jepang di Minangkabau. Selama pemerintahan Jepang nagari tidak lagi dipimpin oleh penghulu, tetapi sebagian besar dijabat oleh orang kalangan rakyat biasa. Nagari sebagai unsu pemerintahan terkecil menurut adat Minangkabau dibagi menjadi unit yang lebih kecil, dikenal dengan Jorong yang dipimpin oleh ketua Jorong. Ketua Jorong telah berperan untuk menyelesaikan segala permasalahan di lingkungannya masing-masing. Kadangkadang dalam penyelesaian permasalahan tersebut tidak mengikutsertakan penhulu sebagai kepala suku seperti masa silam.

Setelah kemerdekaan, di Zaman Pemerinahan Orde Lama tidak jarang ditemukan penghulu serta mamak lainnya, mengikuti kegiatan politik yang bertentangan dengan kemenakan. Setelah pemberontokan Partai Komunis Indonesia 1965, penghulu serta mamak yang terlibat dipecat dan diganti sesuai dengan instruksi pemerintah. Keterlibatan penghulu dan mamak dalam partai terlarang tersebut menyebabkan wibawanya hilnag. Kemenakan selama ini berpandangan bahwa penghulu (pemimpin suku) serta mamak sebagai contoh teladan, bak pepatah adat : Kapai tampek batanyo, Kapulang tampek babarito (Pergi tempat bertanya, pulang tempat bercerita), sudah tidak dipercaya lagi oleh kemenakan. Balai adat masa silam ramai dikunjunggi oleh mamak serat penghulu untuk memperbincangkan masalah yang dihadapi kemenakannya sudah tidak ditemukan lagi.

Balai adat merupakan bangunan yang disangga tiang besar, berlantaikan papan dengan atap bermotifkan tanduk kerbau yang modelnya tidak jauh berbeda dengan rumah gadang. Akhir-akhir ini balai adat sudah banyak yang tidak terpelihara, sebagian besar balai adat telah bocor. Dindingnya sudah habis dimakan binatang kecil 
sehingga bentuknya kelihatan tidak utuh lagi. Sebagian nagari membangun balai adat nagari bersamaan dengan pembangunan kantor nagari yang tempatnya di letakan di tingkat dua.

Sistim pemerintahan Indonesia sejak kemerdekaan sampai akhir-akhir ini masih mewarisi sisa sistim Pemerintahan Belanda. Sehubungan dengan hal itu ketetapan MPR No.IV/MPR/1978 dinyatakan perlu dirumuskan Undang-undang tentang pemerintahan desa yang bertujuan untuk menguatkan pemerintahan desa agar semakin mampu mengerakkan partisipasi masyarakat (LKAAM, 1987 :56).

Untuk merealisasikan ketetapan MPR itu, maka lahirlah undang-undang No.5 Tahun 1979 tentang pemerintahan desa yang dilaksanakan dengan peraturan daerah tingkat I No. 7 Tahun 1981.

Pemerinahan Daerah Tingkah I Propinsi Sumatera Barat merubah Jorong sebagai unit terkecil dari nagari menjadi desa, dengan maksud untuk mendapatkan bantuan desa lebih banyak, dengan mengabaikan kedudukan adat serta hukum adat Minangkabau. Nagari di Minangkabau merupakan kesatuan adat, kesatuan pemerintahan serta kesatuan masyarakat, seperti ungkapan adat berikut : Adaik salingka nagari, pusako salingka suku (adat selingkar nagari, pusaka selingkar suku ).

Setelah terbentuk desa, nagari sebagai kesatuan adat serta sebagai kesatuan pemerintahan terkecil tidak utuh lagi. Kemenakan satu suku serta harta pusaka yang tersebar dalam satu nagari menjadi terpecah belah, selanjutnya membatasi wewenang penghulu dalam memimpin kemenakannya. Perpecahan nagari menjadi beberapa desa menyebabkan pertengkaran mengenai harta pusaka, karena diantara anggota masyarakat merasa bagian desa tertentu yang sudah berbeda pemimpinannya.

Pengangkatan penghulu jarang dilakukan setelah penghulu terdahulu meninggal dunia, tidak jarang ditemukan kampuang atau suku tidak mempunyai penghulu sebagai pemimpin mereka. Pemilihan serta pengangkatan penghulu membutuhkan tenaga serta biaya yang tidak sedikit. Walaupun mereka mempunyai pemimpin tetapi tidak bergelar datuk lagi seperti masa silam.

Untuk mengangkat penghulu yang sudah lama yang tidak diresmikan tersebut, akhir-akhir ini sudah diambil alih salah seorang saudara yang berduit atau yang memegang jabatan dikalangan pemerintahan untuk diresmikan sebagai penghulu 
memimpin sebuah suku. Sehingga jabatan sebagai penghulu akhir-akhir ini dipandang penting dikalangan pemerintahan dan pedagang yang berhasil di rantau.

Di daerah tertentu di Minangkabau, seperti Kodya Payakumbuh dan Kabupaten Lima Puluh Kota, pengangkatan panghulu diresmikan secara masal untuk satu kecamatan. Proses pelaksanaannya dipusatkan di satu tempat dengan jadwal dan acara yang sudah disusun oleh pemerintah daerah setempat. Pada umumnya gelar sebagai penghulu diminati oleh anggota keluarga penghulu yang memegang jabatan di pemerintahan dan pedagang dipandang berduit, seperti: Kepala Desa, Camat, Bupati, Wali Kota, konglomerat dan sebagainya. Tidak jarang ditemukan para pejabat, memakai nama diiringgi oleh gelar datuk dalam kedinasan.

Sehabis peresmiaan pengangkatan penghulu, mereka disibukan oleh tugas-tugas masing-masing yang sebagian bsar tidak berada di kampung. Kehadiran penghulu di kampung dikala diundang untuk rapat yang diadakan Kerapatan Adat Nagari (KAN) atau di lingkungan kaum atau sukunya. Sebagian tugas penghulu, diserahkan kepada salah seorang anggota keluarga untuk mewakilinya.

Sawah kagadangan masa yang silam disediakan untuk penghulu dan hasilnya digunakan untuk penopang pelaksanaan tugas sehari-hari, dewasa ini telah dibagi rata untuk semua anggota keluarga samande dalam satu kaum. Sebagian besar penghulu di Minangkabau tidak mempunyai sawah kagadangan, sehingga untuk membiayai kehidupan pribadi serta anak dan istrinya, mereka pergi merantau untuk berdagangan, bekerja di instasi pemerintah atau swasta.

Sebagian besar saudara laki-laki anggota keluarga yang berhak dan memenuhi syarat untuk menyandang gelar penghulu, memimpin suku atau kaum menantikan penghulu yang telah meninggal dunia, tidak jarang menolak jabatan tersebut. Mereka tidak sanggup menjalankan tugas sebagai penghulu di samping tugas-tugas sebagai ayah dan suami di lingkungan keluarga istri. Begitu juga posisi dan jabatan sebagai malin, manti, dubalang sudah tidak populer ditelinga masyarakat, bahkan sebagian masyarakat tidak mengenal lagi posisi tersebut. Posisi manti, malin, dubalang telah diganti oleh posisi baru dalam struktur pemerintahan desa.

Pemerintahan Daerah tingkat I Propinsi Sumatera Barat, menyadari pentingnya untuk menjaga keberadaan adat di lingkungan masyarakat Minangkabau, maka lahirlah 
Perturan Darah No.13 Tahun 1983 tentang nagari sebagai kesatuan masyarakat hukum adat. Setelah lahirnya Peraturan Pemerintah Daerah No.13 Tahun 1983 tersebut, maka landasan lahirnya Kerapatan Adat Nagari (KAN) memberi peluang bagi penghulu dan mamak untuk memimpin kemenakan kembali, namun apabila diamati lebih lanjut anggota Kerapatan Adat Nagari tidak diambil dari penghulu suku bergelar datuk seperti masa silam.

Di samping itu, Kerapatan Adat Nagari (KAN) menurut UU No.5 Tahun 1979 diberi peranan dalam pengurusan adat dan kebiasaan anak nagari, namun dalam Peraturan Daerah Sumatera Barat No.13 Tahun 1988 dijadikan lembaga tanpa wewenang urusan pemerintahan telah dilaksanakan oleh kepala desa. Sehingga terjadi dualisme pemerintahan di desa yang membigungkan masyarakat, selnjutnya ikut menurunkan wibawa penghulu di mata kemenakannya. Hal ini sesuai dengan ungkapan adat : Manjua bamurah-murah,batimbang jawab ditanyo.Panghulu jiko pacah,Adaik jo nagari indak baguno (Menjual bermurah-murah, bertimbang jawab ditanya. Penghulu jika pecah, adat dengan nagari tidak berguna). Cincin banama ganto sori, sasuai sajo di kalingkiang.Hilang picayo anak nagari, kato jo karajo indak sasuai. (Cincin bernama ganto suri, sesuai saja di kelingking. Hilang percaya anak negeri, kata dengan pekerjaan tidak sesuai) (Hasbi,1993:23)

Dewasa ini segala permasalahan yang menyangkut dengan adat istiadat, seperti perkawinan, penyelesaian sengketa harta pusaka serta sako, penyelesaiannya diserahkan terlebih dahulu kepada Kerapatan Adat Nagarti (KAN). Setelah Kerapatan Adat Nagari menemukan penyelesaian permasalahan melalui musyawarah, tidak jarang ditemukan masyarakat yang bermasalah tidak puas dengan keputusan yang telah diambil, sehingga tidak jarang kasus-kasus yang telah diselesaikan oleh Keraparatan Adat Nagari bermuara ke pengadilan, karena kepercayaan masyarakat atas kemampuan penghulu seperti anggota Kerapatan Adat Nagari (KAN) lainnya sudah berkurang.

Berkurangnya kepercayaan masyarakat atas kemampuan penghulu dalam membimbing kemenakannya, membawa pengaruh kepada mamak tunganai yang selama ini memimpin rumah gandang. Mamak Tungganai mengkoordinir mamak lainnya serta anggota keluarga rumah gadang sudah tidak ditemukan di lingkungan masyarakat Minangkabau. Mamak sebagian besar pergi meninggalkan kampung untuk 
berdagang atau bekerja di instansi pemerintah/swasta. Begitu juga mamak yang tinggal di kampung, mereka tinggal di lingkungan anak dan istinya dan mengunjunggi saudara perempuan dan kemenakan apabila ada suatu keperluan seperti salah seorang anggota keluarga sakit, meninggal, pesta serta permasalahan menyangkut dengan harta pusaka.

Keluarga saparuik (Satu rumah gadang) telah memecah diri menjadi keluarga samande yang kepemimpinannya diambil alih oleh sumando. Sumando dalam keluarga samande mengambil alih fungsi mamak sebatas aktifitas di lingkungan keluarga samande, sedangkan segala sesuatu yang menyangkut dengan harta pusaka serta pelaksanaan perkawinan masih dilaksanakan oleh mamak. Apabila sumando telah meninggal dunia atau saudara perempuan sakit-sakitan tidak jarang untuk pebiayaan kebutuhan kemenakan diambil alih oleh mamak yang sudah berduit, dengan memberikan sebagian bantuan untuk baiaya sekolah.

\section{Perubahan Fungsi Mamak dalam Pemenuhan Ekonomi Keluarga}

Setelah Abad 19 kesempatan untuk merantau dan menerima pendidikan secara Barat terbuka untuk masyarakat Minangkabau, sehingga lapangan pekerjaan sebagai petani mulai beralih ke sektor lain, seperti: perdagangan, pegawai dan sebagainya. Harta yang diperoleh melalui usaha sendiri disebut dengan harta penghasilan semakin menonjol dibandingkan dengan harta pusaka. Harta penghasilan diperbolehkan secara adat untuk diwariskan kepada anak dan istri, sehinga pertanian dan harta pusaka bukan merupakan satu-satunya sumber kehidupan masyarakat Minangkabau.

Bersamaan dengan hal itu, pertumbuhan penduduk di Minangkabau dewasa ini semakin pesat, jika dibandingan dengan luas lahan dengan jumlah kepala keluarga ratarata penguasaan lahan pertanian per keluarga di bawah 1 ha (67\%). Bahkan berdasarkan survey yang pernah dilakukan di salah satu desa di sumatera Barat ditemukan penguasaan lahan rata-rata setiap keluarga hanya 0,2 ha. Luas lahan yang kecil dan sempit itu dimiliki secara komunal (Anam, 1982; Miko,1991).

Harta pusaka yang ada tidak mencukupi kehidupan maka keluarga saparuik (satu nenek) memecah diri menjadi beberapa keluarga samande (satu ibu). Selaras dengan pemecahan itu maka gagam bauntuak yaitu hak menggunakan tanah pusaka diperuntukan kepada keluarga samande. Untuk memenuhi kebutuhan hidup keluarga 
samande tidak dapat mengantungkan hidup semata kepada harta pusaka, maka kehidupan keluarga samande tergantung dengan harta penghasilan sumando.

Harta puska yang ada dikelola secara kolektif di bawah pengawasan mamak masa silam, telah dibagi rata sesuai dengan jumlah keluarga samande. Selanjutnya sawah dan ladang harta pusaka bagian keluarga samande tersebut, sebagian disertifikatkan oleh masyaraka Minangkabau sesuai dengan Undang-Undang Pokok Agararia No.5 Tahun 1960 dan Peraturan Pemerintah No.10 Tahun 1961 yang mengharuskan tanah didaftarkan. Pemilikan serta penguasaan harta pusaka telah beralih kepada keluarga samande.

Mamak kehilangan hak untuk menguasai harta pusaka, seperti masa silam. Harta pusaaka dalam masyarakat Minangkabau masa silam dimiliki oleh saudara perempuan dan dikuasi oleh mamak dengan membagi pengelolaannya secara bergulir. Hasil pengelolaah lahan pertanian tersebut dimanfaatkan oleh saudara perempuan untuk memenuhi kebutuhan keluarganya. Pembagian harta pusaka ditentukan oleh mamak batas-batasnya, dengan maksud supaya jangan terjadi perselisihan antara saudara perempuan yang ada. Setelah tanah tersebut disertifikatkan maka hak menguasai tanah pusaka diambil alih oleh saudara perempuan dalam keluarga samande.

Mamak tungganai, mamak lainnya serta anggota keluarga rumah gadang bekerja bersama-sama di sawah dan ladang seperti masa silam tidak ditemui lagi, Bagitu juga dalam perbaikan bendungan, tali bandar (saluran air) untuk mengaliri air ke sawah-sawah, mamak serta anggota keluarga saparuik, sakampuang serta sasuku bekerja secara bergotong royong tidak ditemukan lagi. Perbaikan bendungan dan tali bandar dewasa ini, dilakukan secara bergortong royong dibawah inisiatif kepala desa dengan memanfaatkan bantuan desa dari pemerintah. Pengaturan penanaman serta pengairan yang selama ini memeberikan kesempatan terlebih dahulu kepada keluarga yang mempunyai sawah diujung bandar atau aliran air tidak berjalan lagi. Sebagian besar masyarakat bertanam sesuai dengan keadaan musim. Apabila musim hujan datang mereka bersiap-siap untuk membibitkan padi untuk bertanam tanpa adanya pengaturan penanaman.

Keluarga samande yang terdiri dari anak, istri dan suami telah memanfaatkan rumah hasil buatan mereka di sekitar rumah gadang. Sumando selama ini tidak 
menetap di lingkungan keluarga istri telah berubah menjadi menetap. Rumah gadang sebagai tempat tinggal keluarga saparuik (satu nenek) sudah mulai ditinggalkan keluarga samande (satu ibu). Di sekitar rumah gadang banyak ditemukan rumah bangunan baru yang dibuat oleh sumando dengan model yang jauh berbeda dengan rumah gadang.

Pembangunan rumah dewasa ini jauh berbeda dengan pembangunan rumah masa silam, baik dalam penggunaan bahan bangunan maupun tata cara membangunnya. Bahan bagunan yang digunakan tidak dominan kayu, karena kayu besar seperti bahan bangunan yang digunakan untuk membangun rumah gadang susah didapat. Sebagian besar masyarakat menggunakan bata, semen dan kayu untuk konsen serta pintu. Kehadiran mamak serta anggota keluarga saparuik, sasuku, serta sakampuang untuk bekerja bersama untuk mendirikan sebuah rumah tidak ditemukan lagi. Begitu juga dalam menetapkan ukuran serta model rumah yang akan dibangun, jarang dimusyawarahkan melalui rapat dalam keluarga saparuik seperti masa silam. Pembangunan rumah dilaksanakan oleh tukang yang telah menguasai teknik bangunan melalui sistim upah harian, mingguan atau borong. Sedangkaan kebutuhan untuk pembangunan, seperti kayu, semen dibeli oleh sumando dengan memanfaatkan harta penghasilannya sendiri.

Kehadiran mamak di lingkungan keluarga ibunya sudah mulai berkurang, mamak berpandangan bahwa tanggung jawab memenuhi kebutuhan ekonomi rumah tangga dalam keluarga samande merupakan tanggung jawab sumando. Segala tanggung jawab saudara laki-laki istri (mamak) selama ini diambil alih oleh sumando di rumah istrinya. Akatifitas mamak sudah mulai berkurang di lingkungan keluarga saparuik (satu ibunya) yang hidup di rumah gadang seperti masal silam. Sawah dan ladang harta pusaka tinggi dari keluarga laki-laki, awalnya digarap seimbang dengan harta istrinya. Lama-kelamaan harta pusaka keluarga samande menurut garis keturunan ibu digarap sepenuhnya oleh sumando bersama kemenakan dan saudara perempuannya. Sedangkan mamak menggarap sawah dan ladang milik istrinya pula. Kewajiban untuk membiayai kemenakan serta saudara perempuan diambil alih oleh sumando (suami saudara perempuan). Kehidupan keluarga samande diambilkan dari harta penghasilan sumando serta harta pusaka bagian keluarga samande. 
Setelah hubungan suami istri semakin dekat dengan keluarga samande, mamak yang bekerja sebagai petani ditemukan lebih banyak menggunakan waktunya mengelola lahan pertanian milik istri dari pada milik saudara perempuannya seperti masa silam. Apabila mamak menanami sawah atau ladang pusaka ibunya, maka hasil pengelolaannya tidak dapat diberikan untuk anak dan istri. Begitu juga mamak yang bekerja sebagai pedagang dan pegawai, mereka memanfaatkan penghasilan yang diperolehnya untuk anak dan isti dalam keluarga samande. Mamak dewasa ini dalam keluarga matrilinial di Minangkabau mulai melepaskan tanggungjawab terhadap kemenakan dan saudara perempuannya. Merantau dan bekerja di luar sektor pertanian semakin hari semakin populer. Tidak jarang ditemukan penganten baru sehabis menikah berangkat meningalkan kampung karena mereka berpandangan selagi tinggal di kampung tidak akan dapat menggumpulkan kekayaan serta mengurus rumah tangga sendiri.

Kebutuhan keluarga samande semakin meningkat, sehingga beban sumando memenuhi kebutuhan ekonomi keluarga semakin berat. Sebelum mata hari terbit ditemukan sebagian sumando yang bekerja sebagai petani memakai baju lusuh dengan membawa ladiang (parang), cangkul pergi ke ladang atau sawah untuk bertani. Begitu juga sumando yang berdagang membawa barang dagangannya yang dibungkus dengan palastik besar menunggu angkutan di pinggir jalan menuju tempat mereka berdagang. Di sela-sela berdagang tersebut, sumando pergi ke ladang untuk menanam kacang jagung serta kulit manis. Setelah mata hari mulai terbenam mereka pulang untuk berkumpul kembali dengan istri dan anak-anaknya. Pada hari pakan (pasar pedesaan) ramai dikunjunggi pembeli dan pedagang, beberapa orang sumando datang dari arah utara dan selatan pasar membawa hasil pertanian dan perternakan, seperti kulit manis, itik, ayam dan sebagainya.

Pemenuhan kebutuhan ekonomi serta pengeluaran rumah tangga sudah mulai bergeser. Istri dan anggota keluarga lainnya sudah mulai terlibat di samping suami dalam pemenuhan kebutuhan ekonomi rumah tangga. Tidak jarang ditemukan ibu-ibu yang bekerja sebagai pedagang, setelah melaksanakan sembahyang subuh turun ke dapur menyiapkan sarapan pagi untuk keluarga, selanjutnya mendorong gerobak berisikan barang dagangannya menuju ke pasar pedesaan. 
Begitu juga ibu-ibu yang bekerja sebagai penjahit, pegawai dan sebagainya. Sebelum melaksanakan pekerjaannya mereka menyiapkan makanan dan pakaian untuk anak-anak yang akan berangkat ke sekolah. Apabila ibu-ibu tersebut mengalami kesulitan melaksanakan tugasnya, bantuan anak tertua sangat diharapkan. Ibu-ibu di Minangkabau berpadangan bahwa mereka bekerja untuk meringankan beban suami dalam memenuhi kebutuhan ekonomi keluarga.

Mamak mengunjunggi saudara perempuan pada waktu tertentu, seperti melihat harta pusaka milik saudara perempuan habis ditaruko urang (diambil orang), salah seorang anggota keluarga sakit, meninggal serta pesta perkawinan. Apabila saudara perempuan tidak sanggup mengelola harta pusaka bagiannya, maka mamak mencarikan orang lain yang akan mengelolanya.

Pengelolaan sawah dan ladang diserahkan kepada petani lain, dilakukan dengan perhitungan pasaduoan (perseduaan) dan parampek an (perempatan). Pengelolaan dengan perhitungan pasaduoan dalam penanaman padi dilakukan dengan perjanjian bahwa pemilik membelikan pupuk, membayar upah tanam serta manyiang (membersihkan semak belukar) dan seperdua hasil panen diambil oleh pengelola. Sedangkan parapek an (perempatan) dengan perjanjian pemilik sawah tidak ikut membelikan pupuk, upah siang dan tanam maka seperempat dari hasil panen untuk pengelola. Begitu juga dalam pemeliharaan tanaman lainnya, seperti kulit manis, mulai dari membersihkan belukar sampai dengan panen sebagian besar diupahkan masyarakat kepada petani penggarap.

Mengusir hama perusak tanaman, seperti babi liar, hari Selasa, Rabu dan Minggu mamak dan sumando berkumpul diperempatan jalan depan kantor kepala desa, depan lapau, depan pos rundo (pos ronda) setempat pergi berburu babi. Dalam berburu babi, anjing memegang peranan penting sehingga harganya melebihi harga seekor sapi atau kerbau. Mamak berpandangan anjing yang baik untuk berburu mempunyai tandatanda sebagai berikut: teliga berdiri, pusar-pusar di kepala kiri dan kanan, badan tinggi serta ramping dan berbulu kasar. Di hari perburuan yang telah ditetapkan, ratusan pemburu dari kelompok perburuan menuju lokasi dengan membawa ajing. Tidak jarang ditemukan dalam satu kali perburuan dapat memusnahkan puluhan ekor babi hutan. 
Apabila sumando telah meninggal dunia, beban untuk memenui kebutuhan keluarga dilakukan oleh saudarra perempuan bersama anak tertua. Tidak jarang ditemukan sepeninggal suaminya saudara perempuan bekerja sebagai pedagang, pengrajin dengan memanfaatkan kemampuannya. Sebagian besar pasar pedesaan Minangkabau ditemukan ibu-ibu menjual makanan, bumbu, sayur-sayuran dan sebagainya.

Apabila saudara perempuan bersama anak tertuanya mengalami kesulitan untuk memenuhi kebutuhan ekonomi rumah tangganya, mamak ikut memberikan bantuan untuk meringankan beban ekonomi keluarga saudara perempuannya. Diwaktu menyambut lebaran tidak jarang ditemukan kiriman oleh mamak dari rantau dalam bentuk uang maupun pakaian untuk saudara perempuan dan kemenakannya. Bantuan mamak tersebut tergantung hubungan mamak dengan saudara perempuannya. Apabila mamak memperhatikan saudara perempuannya, begitu juga sebaliknya maka bantuan akan mengalir untuk memenuhi segala kebutuhan saudara perempuan beserta anakanaknya.

\section{Perubahan Fungsi Mamak dalam Membimbing Kemenakan}

\section{Pengenalan Adat Istiadat.}

Setelah pemerintah Hindia Belanda memperkenalkan tanaman kopi dan pala, maka pertanian orientasi ekspor semakin meluas di Minangkabau. Untuk memenuhi kebutuhan pegawai membantu Pemerintah Hindia Belanda, di Padang dan Bukittinggi didirikan sekolah kelas I, kemudian menyusul sekolah lanjutan di Bukittinggi yang muridnya terbatas kepada orang terkemuka (Bimbin,1971:34).

Sekolah-sekolah yang didirikan Pemerintah Hidia Belanda awalnya kurang diterima masyarakat Minangkabau, tetapi dengan memasukan pelajaran agama dalam kurikulum sekolah tersebut selanjutnya masyarakat mulai menerimanya. Setelah Indonesia merdeka, kesempatan menekuni pendidikan terbuka luas, pemerintah menyadari ketertinggalan masyarakat di bidang pendidikan, maka dibangunlah SD Inpres, SMP, SMA, M Ts N, MAN di setiap desa dan kecamatan. Perkembangan salanjutnya, dualisme antara pendidikan agama dengan pendidikan umum mulai hilang setelah perubahan kurikulum $\mathrm{M}$ Ts $\mathrm{N}$ 
dengan porsi pelajaran pendidikan umumnya sama dengan SMP, Madrasah Aliyah (MAN) sama dengan SMA.

Surau sebagai pusat pendidikan informal di Minangkabau ditinggalkan oleh masyarakat. Mamak dan kemenekanan berkumpul di surau pada malam hari sudah tidak ditemukan lagi. Sebagian besar mamak sudah pergi merantau dan tinggal bersama anak dan istrinya. Surau yang selama ini tempat belajar mengaji dan adat istiadat tidak ditempati lagi, sehingga semakin lama semakin rubuh dimakan binatang kecil. Sebagian besar surau telah dibuka dan diganti dengan bangunan baru yang modelnya hampir sama dengan mesjid, disebut masyarakat dengan musallah. Musallah dibuka saat waktu sembahyang datang serta ceramah agama diadakan.

Membimbing kemenakan diambil alih oleh sumando dalam keluarga samande. Keterbatasan kemampuan dan waktu sumando untuk mendidik anak sesuai dengan kebutuhan zaman, sumando menyerahkan anaknya ke sekolah formal. Apabila anak sudah menginjak umur empat atau lima tahun dimasukan ke Taman Kanak-kanak (TK). Bagi keluarga yang berduit di perkotaan anak-anak sebelum umur empat tahun dimasuk ke Play Group dengan biaya yang mahal. Satu atau dua tahun setelah dimasukan ke Taman Kanak-kanak, anak dimasukan ke Sekolah Dasar (SD). Apabila ekonomi mereka sudah memungkinkan, anak tersebut diserahkan lebih lanjut ke SMP, SMA dan Perguruan Tinggi. Di samping melalui pendidikan umum, anak juga diserahkan untuk belajar mengaji Ke Taman Bacaan Al Quran (TPA) yang ada di setiap nagari.

Sumando masa silam dalam masyarakat Minangkabau di kenal datang pada malam hari dan kemenakan laki-laki tidur di surau tidak ditemukan lagi. Kemenakan sejak dari dalam kandungan sudah bergaul secara dekat dengan sumando yang selama ini tidak dijumpai dalam masyarakat Minangkabau tradisional. Tidak jarang ibu-ibu yang sedang hamil besar ditemani oleh suaminya berjalan di pagi hari untuk berolah raga agar memudahkan proses kelahiran anaknya.

Kemenekan sejak darikecil sudah diperkenalkan oleh sumando dan saudara perempuan dalam kelaurga samande dengan sopan santun dalam bergaul 
yang dulunya dilakukan oleh mamak di lingkungan rumah gadang. Setelah kemenakan menginjak dewasa sumando dan saudara perempuan mulai memperhatikan cara mereka berpakaian. Kemenakan yang sudah menginjak dewasa diharapkan oleh sumando dan saudara perempuan supaya dapat memakai pakaian yang indah, sopan dan dapat menutup aurat. Bebeda dengan harapan mamak masa silam yang menuntut kemenakan perempuan untuk memakai baju kuruang.

Sumando dan saudara perempuan menanamkan sopan santun kepada kemenakan sebelum makan. Awal kemenakan belajar makan, sumando dan saudara perempuan menunjukkan kepada kemenakan untuk menggunakan tangan kanan dan mencucinya terlebih dahulu lebih makan. Selanjutnya saudara perempuan dan sumando membiasakan kemenakan mengunyah makanan agar tidak berbunyi (mancapak), begitu juga dalam menggunakan sendok. Selama makan, nasi tidak boleh bertebaran dan bila mulut masih penuh dengan makanan tidak boleh berbicara.

Kemenakan yang sudah bersekolah, apabila jam sudah menunjukkan jam sembilan atau sepuluh malam, terlihat sumando dan saudara perempuan menyuruh tidur. Kemenakan perempuan yang sudah menginjak dewasa tidak diperbolehkan untuk tidur satu kamar dengan kemenakan laki-laki, kecuali kemenakan laki-laki yang masih kesil atau anak-anak. Begitu juga sebaliknya kemenakan perempuan disuruh tidur di kamar dan tidak diperbolehkan tidur di ruang tengah atau tamu.

Di dalam keluarga samande, kemenakan laki-laki maupun perempuan sejak kecil suduah didik oleh saudara perempuan dan sumando untuk saling mengasihi. Sumando dan saudara perempuan dipandang oleh kemenakan sebagai orang pertama yang memelihara, menjaga, mengasuh serta memenuhi segala kebutuhannya sejak dari kecil sampai dewasa. Penghormatan kemenakan kepada mamak seperti masa silam telah beralih kepada sumando dan saudara perempuan.

Seiring dengan semakin menonjolnya keluarga samande (satu ibu) dibandingkan dengan keluarga saparuik (satu nenek), hubungan sumando dengan anggota keluarga samande mulai berubah. Sumando selamaini datang pada malam hari sekarang telah tinggal menetap bersama keluarga samande dengan melakukan aktifitas, seperti bertani ke sawah dan ladang, berdagang bersama keluarga 
samande lainnya. Begitu juga kemenakan laki-laki sebelum menikah tidur di rumah ibu, dengan menempati bagian kamar terpisah dari kamar yang ada di rumah induk disebut dengan rumah dapua.

Hubungan yang tidak begitu dekat salama ini dengan saudara istri serta mertua telah berubah bagaikan hubungan kakak dengan adik serta orang tua dengan anak. Larangan sumando menggunakan tempat mandi yang sama dengan anggota keluarga samande istri lainnya tidak dipermasalahkan, karena masyarakat Minangkabau sebagian besar telah membuat kamar mandi di setiap rumah yang diperuntukan untuk keluarga samande. Pemandian umum, seperti pencuran yang sebagian masyarakat yang menggunakannya lagi.

\section{Pendidikan Agama}

Setelah Abad 19 pemerintah Hindia Belanda mendirikan sekolah yang awalnya kurang diterima masyarakat Minangkabau. Setelah pelajaran agama merupakan salah satu mata pelajaran yang dipelajari di sekolah tersebut, maka masyarakat mulai menerimanya. Sekolah merupakan alternatif lain bagi masyarakat Minangkabau untuk belajar agama selain di surau.

Masyarkat Mingkabau mulai mengenal membaca dan menulis latin, walaupun sebelumnya mereka telah mengenal membaca dan menulis arab yang dipelajari di surau. Setelah kemerdekaan, kesempatan untuk menerima pendidikan terbuka luas. Di dalam kurikulum sekolah-sekolah, pendidikan agama termasuk mata pelajaran wajib dipelajari.

Mamak selama ini berda di kampung dan siap setiap waktu membimbing serta mendidik kemenakan telah mulai meninggalkan kampung untuk merantau. Pada awalnya merantau semusim dan akhirnya sebagian besar menetap di rantau. Kadang-kadang mereka pulang sekali dalam setahun, seperti : Hari Lembaran, namun mereka sebagian besar berada di rumah istri bersama anak dan istrinya.

Kemenakan kehilangan tokoh pembimbing yang disegani, seperti masa silam. Pendidikan agama untuk kemenakan diambil alih oleh sumado dan saudara perempuan dalam keluarga samande. Remaja laki-laki selama ini tidur di surau sudah berkumpul bersama ibu, Bapak serta saudara perempuannya untuk membantu 
menyelesaikan tugas orang tua serta mengulang pelajaran yang telah dipelajari di sekolah. Saudara perempuan dan sumando menanamkan agama sejak dari kecil kepada kemenakan. Kemenakan yang sudah bisa berjalan dibawa ke mesjid untuk mengikuti sembahyang berjemaah ke mesjid.

Di bulan puasa kemenakan sudah bermur kira-kira tujuh tahun, tidak jarang ditemukan ikut melaksanakan pausa bersama saudara perempuan, sumando sera saudara lainnya. Bagi anak yang dapat menjalankan ibadah pausa dengan penuh, sering diberi hadiah oleh sumando atau saudara perempuan berupa uang atau mainan yang disukai oleh anak tersebut.

Orang tua mengharapkan anaknya bisa membaca Al Quran serta taat menjalankan sholat lima waktu. Apabila anak tersebut tidak bisa membaca Al Quran mereka sangat terhina. Orang tua mengharapkan setelah meninggal dunia sering dibacakan Al Quran oleh anaknya, karena mereka berpandangan anak soleh adalah yang dapat mebantu mereka apabila mendapat siksaan kubur.

\section{Pendidikan Seni dan Bela Diri.}

Setelah harta penghasilan dan keluarga samande semakin menonjol, merantau yang awalnya dilakukan oleh mamak secara berkala untuk menunggu panen datang. Lama kelamaan mereka menetap di ratau bersama anak dan istrinya. Kemenakan selama ini dibimbing oleh mamak untuk belajar bersilat dan tidak ditemukan lagi. Kemenakan kehilangan pembimbing yang akan menghajar bersilat. Pendidikan kemenakan diambil alih oleh sumando dan saudara perempuan dalam keluarga samande. Sumando dan saudara perempuan sebagai tokoh penganti mamak dalam keluarga. Kemampuan bersilat yang diberikan oleh mamak selama ini, tidak pernah diberikan sumando kepada kemenakan.

Keterampilan bersilat dewasa ini sudah jarang dimiliki oleh sebagian lakilaki di Minangkabau. Apabila diamati lebih lanjut ditemukan pelajaran bersilat diikuti oleh laki-laki remaja yang mempunyai minat untuk mendalami sebagai salah satu cabang olah raga bela diri. Tempat belajar silai selama ini, di pamedanan di sekitar surau diambil alaih oleh perguruan silat dengan guru yang dipandang sudah menguasainya. 
Setiap tahun pemerintah Kabupaten/Kota terlihat mengadakan lomba silat yang pelakanaannya bertepatan dengan peringatan hari Kopri (Korp Pegawai negeri Sipil Republik Indonesia) Lomba silat diikuti oleh bebera perguruan silat yang ada di Kabupate/kota. Di samping olah raga silat, sebagain remaja yang sudah menginjak dewasa ditemukan mengikuti latihan bela diri, seperti karate yang dilaksanakan setiap minggu di pusat Kabupaten.

Keseniaan randai jarang diadakan pertunjukkannya, pengemar randai dari hari-kehari semakin berkurang. Pertunjukkan randai sering dilakukan apabila diadakan pekan buaya di pusat Kabupaten/Kota atau Propinsi, atas prakarsa pemerintah daerah setempat. Pemain randai sudah mengalami perubahan, selama ini pemainnya tidak ada diperankan oleh perempuan sekarang telah diperankan oleh perempuan dan acara tersebut kadang-kadang dilaknakan siang hari.

\section{Keterampilan dalam Mengelola Harta Pusaka}

Setelah menonjolnya keluarga samande, pengelolaan harta pusaka diambil alih oleh saudara perempuan bersama sumando. Kemenakan sejak usia muda telah diikutsertakan untuk membantu sumando dan saudara perempuan dalam mengelola harta pusaka. Apabila sumando memiliki keahlian dalam bertukang, dihari libur sekolah tidak jarang ditemukan beberapa nak laki-laki ikut membantu pekerjaan sumando tersebut, begitu juga dalam berdagang.

\section{E. Pelaksanaan Upacara Adat}

\section{Penyelenggaraan Upacara Perkawinan}

Setelah hubugan suami istri semakin rapat dan kehidupan keluarga samande tergantung pada harta penghasilan suami (sumando). Mamak mulai melepaskan tanggung jawabnya terhadap kemenakan dan saudara perempuan. Pemilihan jodoh kemenakan, diambil alih oleh sumando serta saudara perempuan dalam keluarga samande, sedangkan baralek (peresmian pernikahan) dilaksanakan oleh mamak

yang dipimpin oleh penghulu suku (pemimpin suku). Apabila kemenakan perempuan telah menginjak dewasa dan sudah waktunya untuk menikah, sumando dan saudara perempuan mulai memikirkan calon menentunya. Dewasa ini remaja 
laki-laki dan perempuan sebelum memutuskan untuk menikah telah berkenalan terlebih dahulu. Apabila persetujuan untuk berumah tangga sudah ditemukan, pembicaraan dilanjutkan kepada mamak-mamak serta ibu-ibu anggota rumah gadang.

Waktu berlangsungnya acara timbang tando (tukar cincin) serta pernikahan, mamak tungganai, mamak lainnya serta sumando yang dipimpin oleh ninik mamak (peghulu) pergi ke rumah calon mempelai laki-laki dengan membawa pinangan berupa cincin emas. Dalam acara tersebut, mamak tugganai dan mamak lainnya dipimpin oleh penghulu memperbincangkan sangsi bagi calon mempelai yang mengingkari janji untuk menikah, jadwal pernikahan dan peremiannya.

Sebelum timbang tando diadakan, mamak tungganai memerintahkan kepada saudara laki-laki serta perempuan untuk mengundang pasumandan (istri saudara laki-laki), bako (keluarga bapak) serta anggota keluarga lainnya. Saudara perempuan mengundang kerabat perempuan. Sedangkan laki-laki mengundang kerabat laki-laki pula.

Waktu berlangsungnya acara timbang tando (tukar cincin), mamak tungganai, mamak lainnya serta urang sumando yang dipimpin oleh Niniak Mamak (penghulu) pergi ke rumah calon mempelai laki-laki dengan membawa pinangan berupa cincin emas. Dalam acara tersebut, mamak tunggai dan mamak lainnya dipimpin penghulu memperbincangan sangsi bagi calon mempelai yang mengingkari janji untuk menikah, jadwal pernikahan dan peresmiannya.

Sebelum timbang tando diadakan, mamak tungganai memerintahkan kepada saudara laki-laki serta perempuan untuk mengundang pasumandan (istri saudara laki-laki), bako (keluarga Bapak) serta anggota keluarga lainnya. Saudara perempuan mengundang kerabat perempuan, sedangkan laki-laki mengundang kerabat laki-laki pula. Setelah pesta timbang tando cincin sebagai tanda ikatan dua keluarga untuk saling menyetujui menikahkan anak laki-laki dan perempuannya, dipegang oleh penghulu masing-masing calon mempelai. Apabila salah satu fihak tidak menepati janji, permasalahan tersebut diselesasikan oleh kedua penghulu dengan sangsi laki-laki hilang tando (cincin), sedangkan bagi perempuan didenda dua kali lipat harga tando (cincin) tersebut. 
Sesuai dengan jadwal yang telah ditetapkan dalam acara timbang tando untuk melaksanakan pernikahan dan baralek sebagai peresmiannya. Lima belas hari sebelum acara berlangsun mamak yang dituakan (tungganai) memerintahkan kepada kemenakan perempuan dan laki-laki atau saudara perempuan atau laki-laki yang sudah dewasa untuk memberi tahu kembali kepada sumando, bako-baki, kerabat sasuku dan sapasukuaan serta kerabat lainnya untuk menghadiri acara perhelatan peresmiaan pernikahan. Proses pelaksanaan pernikahan serta peresmiannya di Minangkabau tidak jauh berbeda dengan maa silam.

Kebutuhan baralek atau pesta peresmiaan pernikahan, masa silam dibiayai oleh mamak tungganai dari pengelolaaan harta pusaka. Dewasa ini pembiayaan baralek merupakan kewajiban dari orang tua. Sedankang pekerjaan berat dalam proses baralek dilakukan dengan memanggil orang luar untuk mencuci piriang yang dulunya dilakukan secara bergotong royong oleh perempuan keluarga saparuik (satu nenek), dan sekampuang.

Kebiasaan masyarakat Minangkabua masa silam, memanggil sumando dengan gelar pusako yang disebut dengan sako dari keluarga laki-laki yang sudah menikah tersebut. Sesuai dengan ungkapan : Ketek banama, gadang bagala (Kecil bernama dan besar bergelar). Dewasa ini masyarakat cenderung memanggil nama dibandingn dengan gelar (sako). Gelar dipakaian dalam upacara adat seperti baralek dan batimbang tando.

\section{Upacara Kehamilan dan Kelahiran}

Setelah penghasilan keluarga samande semakin menonjol sebagai unit ekonomi utama. Pelasanaan upacara kehamilan dan kelahiran diambil alih oleh saudara perempuan dalam keluarga samande (satu ibu). Mamak jarang sekali mengawasi upacara tersebut seperti masa silam. Mamak berpandangan bahwa kelurga samande bertanggung jawab kepada keluarga, seperti apa yang telah digariskan dalam ajaran Islam.

Pada awal kehamilan, ibu mertua berserta saudara perempuan suami datang ke rumah pasumandan (suami saudara laki-laki) membawa buah-buahan disusun dalam talam (wajan) yang ditutup dengan tuduang pandan, dengan maksud supaya 
menantu bersama janin yang dihamilinya tidak kekurangan vitamin. Pembiayaan upacara tersebut dilakukan oleh saudara perempuan dan sumando dengan memanfaatkan harta penghasilannya, sedangkan masa silam diambilkan dari pengelolaan harta pusuaka oleh mamak.

\section{Upacara Kematian}

Setelah keluarga samande (satu ibu) tergantung dengan harta penghasilan suami, sumando dan saudara perempuan dipandang oleh kemenakan sebagai orang pertama yang memelihara, menjaga, mengasuh serta memenuhi segala kebutuhannya.

Apabila sumando atau saudara perempuan sakit atau meninggal, dirawat atau dikebumikan dengan baik oleh kemenakan sebagai ungkapan membalas kebaikan yang telah diberikan kepadanya. Begitu juga mamak di rumah istri dan anaknya. Kehadiran kemenakan di rumah istri mamak apabila mamak meninggal atau sakit dan tidak berbeda dengan tamu lainnya.

Dewasa ini anak dan istri berpandangan apabila Bapak sakit dan dirawat di rumah saudara perempuannya seperti masa silam, mereka hina dipandang masyarakat, seusai dengan Ungkapan: Habih dagiang tulang bakisai, Habih manih sampah dibuang. (Habis daging tulang dibuang. Habis manis Sempah dibuang).

Pelaksanaan upacara kematian tidak jauh berbeda dengan masa silam namun pelaksanaannya upacara keatian masa silan dipimpin oleh malin. Dewasa ini dilakukan oleh mamak, anak serta kerabat lainnya. Saudara laki-laki ibu atau mamak apabila meninggal dunia tidak jarang ditemukan upacara keatiannya sejak dari memandikan sampai dengan menguburkan dilakukan di lingkungan kelaurga istrinya.

\section{F. Penutup}

Posisi mamak di Minangkabau mulai goyah, setelah pemerintah Belanda menanamkan kekuasaan politiknya dengan mengangkat penghulu sebagai wakil Kompeni. Tugas yang dijalankan penghulu sebagai wakil kompeni sering berbenturan degan kemenakannya, sehingga wibawa penghulu mulai pudar di mata kemenakannya. 
Setelah pemerintah Jepang, nagari dipecah menjadi bagian terkecil disebut dengan jorong. Kepala jorong diambil dari kalangan masyarakat biasa dan diberi wewenang untuk menyelesaikan pemasalahan di lingkungannya tanpa mengikut sertakan penghulu. Selanjutnya di Zaman Orde Lama tidak jarang ditemukan penghulu terlibat dengan partai komunis sehingga dipecat dan diganti sesuai dengan instruksi pemerintah. Setelah pemerintahan nagari sebagai unit terkecil menurut adat Minangkabau pecah menjadi desa, kekuasaan penghulu semakin pudar diganti oleh kepala desa. Walaupun Pemerintah Daerah Tingkat I Sumatera Barat memberdayakan kembali Kerapatan Adat Nagari (KAN) namun anggotanya tidak penghulu lagi. Kehilangan wibawa penghulu selanjutnya bergerak kepada mamak tungganai serta mamak lainnya dalam keluarga. Kekuasaan mamak untuk keluarga samande telah diambil alih oleh sumando. Istilah sumando mamak rumah semakin popular untuk sumando yang berfungsi sebagai sumando dan mamak di kalangan masyarakat Minangkabau.

Selepas abad 19, lapangan pekerjaan sebagai petani di Minangkabau mulai bergeser ke sektor lain, seperti pedang, pegawai dan sebagai. Hata penghasilan semakin menonjol dibandingkan dengan harta pusaka. Harta pusaka tidak dapat memenuhi kebutuhan keluarga, karena pertumbuhan penduduk semakin pesat. Keluarga saparuik (satu nenek) memecah diri menjadi keluarga samande (satu ibu) dan kehidupan tergantung dengan harta penghasilan sumando. Mamak mulai melepaskan tanggung jawabnya terhadap saudara perempuan dan kemenakannya.

Semenjak berdirinya sekolah di lingkungan masyarakat Minangkabau, surau sebagai pusat pendidikan informal mulai ditinggalkan. Mamak dan kemenakan berkumpul di surau untuk mempelajari adat-istiadat tidak ditemukan lagi. Sebagian besar masyarakat berangkat ke rantau dan tinggal bersama anak dan istinya. Pendidikan anak dilakukan oleh sumando dan saudara perempuan. Apabila anak sudah beranjak dewasa si serahkan ke sekolah.

Setelah berdirinya sekolah formal, masyarakat Minagkabau dapat belajar agama di sekolah tersebut. Surau sebagai pusat pendidik agama telah mulai ditinggalkan, mamak danke menakan berkumpul di surau untuk mempelajari agama tidak ditemukan. Surau setelah berubah menjadi musallah dibuka waktu sembahyang 
datang. Pendidikan agama untuk kemenakan diberikan oleh saudara perempuan dan sumando dalam keluarga samande. Keterbatasan waktu sumando untuk memberikan pelajaran agama kepada kemenakan, maka kemenakan diserahkan ke Ibtidaiyah serta sekolah untuk mempelajari agama. Kemenakan diharapkan oleh sumando dan saudara perempuan taat menjalankan sembahyang lima waktu serta dapat membaca Al Quran dengan lancar.

Pelajaran silat masa silam diberikan oleh mamak, dewassa ini tidak ditemukan lagi. Kemampuan bersilat dewasa ini jarang dimiliki oleh laki-laki Minangkabau. Bagi kemenakan laki-laki yang berminat untuk mempelajari silat sebagai olah raga bela diri, dipelajari melalui perguruan silat yang dibimbing oleh guru dipandang menguasainya. Untuk melestarikan seni bela diri tersebut, maka setiap tahun pemerintah daerah setempat mengadakan lomba silat yang diikuti oleh perguruan silat yang ada di sekitarnya. Begitu juga pertunjukan randai sebagai seni tradisional Minangkabau. Jarang sekali diadakan disetiap nagari.

Pengelolaan harta pusaka telah diambil alih oleh sumando dan saudara perempuan dalam keluarga samande. Keterampilan yang diperoleh kemenakan sesuai dengan keahlian sumando dan saudara perempuan. Apabila sumando memiliki keahlian bertukang maka kemenakan diajar bertukang, begitu juga sumando yang memiliki keahlian dalam berdagang. Tanggung jawab mamak dalam pelaksanaan upacara perkawinan serta kematian telah diambil alih sumando bersama saudara perempuan dalam kelaurga samande. 


\section{Daftar Kepustakaan}

Alam, Syamsul (1988) : Pola Penguasaan Tanah dan Mobilitas Sosial di Daerah Pedesaan : Suatu Studi Mobilitas Spatial Masyarakat di Daerah Minangkabau. Disertasi Universitas Padjadjaran Bandung.

Bachtiar, Harsya,W (1963) : Masyarakat Desa Minangkabau, dalam Koentjaraningrat Masyarakat Desa Masa Kini. Jakarta : FE Universitas Indonesia.

Bobin,AB (1992) : Monografi Daerah Sumatera Barat. Jakarta : Dep P dan K.

Budhisantoso,S (1988): Kedudukan dan Peranan Wanita dalam Kebudayaan Suku Minangkabau. Jakarta : Departemen Pendidikan dan Kebudayaan.

Hasbi, Muhamad (1971) : Perkembangan Lembaga Kerapatan Tradisional Ke Arah Lembaga Kerapatan Demokrasi Nagari. Malang : Institut Pemerintahan.

Kato,Tsuyoshi, (1986) : Rantau Pariaman: Dunia Saudagar Pesisir Minangkabau Abad XIX, dalam Akira Nagazumi, Indonesia Kajian Sarjana Jepang Perubahan Sosial Ekonomi Abad XIX dan XX dan Berbagai Aspek Nasionalisme Indonesia. Jakarta : Yayasan Obor Indonesia h.77-115

, (1989) : Matriliny and Migration. Evolving Minangkabau Traditions in Indonesia. Disertasi : Cornell University.

LKAAM, (1987) : Pelajaran Adat Minangkabau (Sejarah dan Budaya). Padang : LKAAM Sumatera Barat.

Miko, Alfan, (1991) : Pekerja Wanita Pada Industri Rumah Tangga Sandang di Propinsi Sumatera Barat. Yogyakarta : Pusat Penelitian Kependudukan Yogyakarta.

Naim, Mochtar, (1984) : Sikap dan Perilaku Masyarakat Minangkabau Mensukseskan Pembangunan. Bandung : Madju.

, (1984) : Merantau : Pola Migrasi Suku Minangkabau. Yogyakarta :

PT. Tiara Wacana.

, (1986) : Dampak Sosial Budaya dari Merantau terhadap Pembangunan Daerah Sumatera Barat, dalam Jurnal Penelitian dan Pengabdian kepada Masyarakat. Univ.Andalas No. II September 1986. 
, (1991) : Kebudayaan Daerah dan Kebudayaan Nasional. Jakarta : Kongres Kebudayaan Nasional.

Firman, (1997) : Adaptasi Fungsi Mamak dalam Perubahan Struktur Keluarga di Minangkabau. Disertasi Universitas Airlangga Surabaya.

, (2003) : Dukungan Sosial dan Penyesuaian Diri Wanita Lanjut Usia di Minangkabau. Padang; Balitbang Propinsi Sumatera Barat.

Hasbi, Muhammad, (1971) : Perkembangan Lembaga Kerapatan Adat Tradisional Kearah Lembaga Kerapatan Demokrasi Nagari. Malang : Institut Ilmu Pemerintahan.

Mardanas, Safwan \& Sutrisno Kutoyo (1981) : Sejarah Pendidikan Daerah Sumatera Barat. Padang : Depdiknas.

Sanderson, Stephen K. (1993) : Sosiologi Mikro. (terjemahan) Jakarta : Rajawali Pers. 
MAKALAH

\title{
POSISI DAN FUNGSI MAMAK DALAM PERUBAHAN SOSIAL DI LINGKUNGAN KELUARGA MATRILINIAL MINANGKABAU
}

\author{
Oleh
}

Dr. Firman.MS

Disampaikan dalam Seminar Warisan Puisi Melayu Serumpun dan Forum Adat, Dilaksanakan Oleh Kerajaan Negeri Melaka, Institut Seni Malaysia (ISMA) dan Dewan Bahasa dan Pustaka, pada Tanggal 5 Oktober 2004 di Melaka.

FAKULTAS ILMU PENDIDIKAN UNIVERSITAS NEGERI PADANG 
2004 